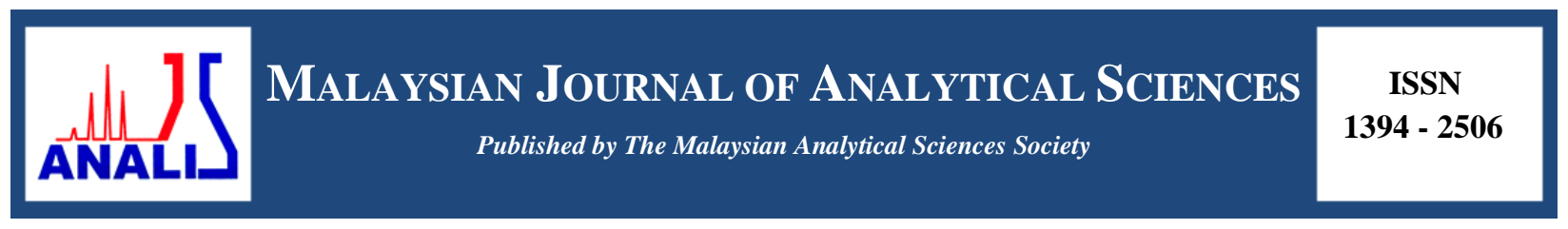

\title{
OXIDATION OF COMMERCIAL PETRONAS DIESEL WITH TERT-BUTYL HYDROPEROXIDE OVER POLYMOLYBDATE ALUMINA SUPPORTED CATALYST MODIFIED WITH ALKALINE EARTH METALS
}

\author{
(Pengoksidaan Diesel Komersial Petronas dengan Tert-Butil Hidroperoksida bersama \\ Pemangkin Polimolibdenum Diubahsuai dengan Logam Alkali) \\ Wan Nazwanie Wan Abdullah, Rusmidah Ali*, Wan Azlee Wan Abu Bakar \\ Department of Chemistry, Faculty of Science, \\ Universiti Teknologi Malaysia, 81310 UTM Johor Bahru, Johor, Malaysia \\ *Corresponding author: rusmidah@kimia.fs.utm.my
}

Received: 9 December 2014; Accepted: 9 October 2015

\begin{abstract}
Due to strict environmental legislation for ultra-low sulfur diesel fuels, increasing technical and operational challenges are imposed to conventional hydrodesulfurization (HDS) technology. Therefore, catalytic oxidative desulfurization (Cat-ODS) has been suggested to be an alternative method to replace a conventional method which is hydrodesulfurization. In this study, catalytic oxidation of commercial diesel was performed using an oil-soluble oxidant, tert-butyl hydroperoxide (TBHP), over polymolybdate supported on alumina $\mathrm{MoO}_{3}-\mathrm{PO}_{4} / \mathrm{Al}_{2} \mathrm{O}_{3}$ catalyst. A commercial Petronas diesel with 440 ppmw of total sulfur was employed to evaluate the elimination of sulfur compounds. Besides, the percentage of sulfur removal was measured by (GCFPD). Alkaline earth metals, such as Calcium (Ca), Barium (Ba) and Strontium ( $\mathrm{Sr}$ ) were introduced on the surface of $\mathrm{MoO}_{3^{-}}$ $\mathrm{PO}_{4} / \mathrm{Al}_{2} \mathrm{O}_{3}$. The results showed that the catalytic activity decreased in the order, $\mathrm{Ca} / \mathrm{MoO}_{3}-\mathrm{PO}_{4} / \mathrm{Al}_{2} \mathrm{O}_{3}>\operatorname{Sr} / \mathrm{MoO}_{3}-\mathrm{PO}_{4} / \mathrm{Al}_{2} \mathrm{O}_{3}>$ $\mathrm{Ba} / \mathrm{MoO}_{3}-\mathrm{PO}_{4} / \mathrm{Al}_{2} \mathrm{O}_{3}$. The $\mathrm{Ca} / \mathrm{MoO}_{3}-\mathrm{PO}_{4} / \mathrm{Al}_{2} \mathrm{O}_{3}$ catalyst was characterized by XRD and FESEM. XRD results showed that the best catalyst was highly amorphous while FESEM micrograph illustrated an aggregation and agglomeration of various particle sizes. The catalytic activity of $\mathrm{Ca} / \mathrm{MoO}_{3}-\mathrm{PO}_{4} / \mathrm{Al}_{2} \mathrm{O}_{3}$ catalyst with various $\mathrm{Ca} / \mathrm{Mo}$ ratios were also studied. When the $\mathrm{Ca} / \mathrm{Mo}$ ratio was 15:85, the sulfur removal was the highest $(79 \%)$ at $45^{\circ} \mathrm{C}, 30 \mathrm{~min}$ and $\mathrm{O} / \mathrm{S}$ molar ratio 3.0 with solvent $=$ dimetylformamide $(\mathrm{DMF}), \mathrm{diesel} /$ solvent ratio $=1.0$.
\end{abstract}

Keywords: Oxidative desulfurization, commercial diesel, tert-butyl hydroperoxide, alkaline earth metals, polymolybdate, dimetylformamide

\begin{abstract}
Abstrak
Disebabkan undang-undang alam sekitar yang ketat untuk bahan api sulfur diesel ultra-rendah, peningkatan cabaran teknikal dan operasi dikenakan kepada hydropenyahsulfuran konvensional teknologi (HDS). Oleh itu, penyahsulfuran oksidatif mengunakan pemangkin (Cat-ODS) telah dicadangkan untuk menjadi satu kaedah alternatif untuk menggantikan kaedah konvensional iaitu hydopenyahsulfuran. Dalam kajian ini, pengoksidaan diesel komersial telah dijalankan menggunakan oksida larut minyak, tertbutil hidroperoksida (TBHP) dan mangkin molibdena berpenyokong alumina, $\mathrm{MoO}_{3}-\mathrm{PO}_{4} / \mathrm{Al}_{2} \mathrm{O}_{3}$. Diesel komersial Petronas yang mengandungi sulfur 440 ppmw telah digunakan untuk menilai penyahsulfuran. Selain itu, peratusan penyingkiran sulfur telah diukur menggunakan (GC-FPD). Logam alkali, seperti Kalsium (Ca), Barium (Ba) dan Strontium (Sr) telah dicelup pada permukaan $\mathrm{MoO}_{3}-\mathrm{PO}_{4} / \mathrm{Al}_{2} \mathrm{O}_{3}$ pemangkin. Hasil kajian menunjukkan bahawa aktiviti pemangkin menurun mengikut susunan, $\mathrm{Ca} / \mathrm{MoO}_{3}-\mathrm{PO}_{4} / \mathrm{Al}_{2} \mathrm{O}_{3}>\mathrm{Sr} / \mathrm{MoO}_{3}-\mathrm{PO}_{4} / \mathrm{Al}_{2} \mathrm{O}_{3}>\mathrm{Ba} / \mathrm{MoO}_{3}-\mathrm{PO}_{4} / \mathrm{Al}_{2} \mathrm{O}_{3}$. Pemangkin $\mathrm{Ca} / \mathrm{MoO}_{3}-\mathrm{PO}_{4} / \mathrm{Al}_{2} \mathrm{O}_{3}$ telah dicirikan menggunakan XRD dan FESEM. Keputusan XRD menunjukkan pemangkin yang terbaik adalah sangat amorfus manakala
\end{abstract}




\section{Wan Nazwanie et al: OXIDATION OF COMMERCIAL PETRONAS DIESEL WITH TERT-BUTYL HYDROPEROXIDE OVER POLYMOLYBDATE ALUMINA SUPPORTED CATALYST MODIFIED WITH ALKALINE EARTH METALS}

FESEM mikrograf menggambarkan satu aglomerasi dalam pelbagai saiz zarah. Aktiviti pemangkin $\mathrm{Ca} / \mathrm{MoO}_{3}-\mathrm{PO}_{4} / \mathrm{Al}_{2} \mathrm{O}_{3}$ dengan pelbagai nisbah $\mathrm{Ca} / \mathrm{Mo}$ telah juga dikaji. Apabila nisbah $\mathrm{Ca} / \mathrm{Mo}$ adalah 15:85, penyingkiran sulfur adalah tertinggi (79\%) pada keadaan optimum: $45^{\circ} \mathrm{C}, 30 \mathrm{~min}$ dan nisbah $\mathrm{O} / \mathrm{S}$ molar $=3.0$ dengan pelarut $=$ dimetilformamida $(\mathrm{DMF})$, nisbah diesel $/$ pelarut $=$ 1.0 .

Kata kunci: penyahsulfuran oksidatif, diesel komersial, tert-butil hidroperoksida, logam alkali, polimolibdena, dimetilformamida

\section{Introduction}

Sulfur in transportation fuels is a major source of air pollution. Ultra-deep desulfurization of fuels is a matter of major interest not only because of increasing environmental concern and legal requirements, but also because ultralow-sulfur fuel is a key requirement for fuel cell applications [1]. In the near future, the requirements for sulfur content in the fuel will become more stringent - with zero sulfur emission from the transport fuel, which calls for the development of advanced technologies for ultra clean fuel. Thus, great efforts have been made todecrease the content of sulfur in diesel oil [2]. HDS can produce lower sulfur level diesel oil, but this technology needs heavy cost in operating and capital. Therefore, oxidative desulfurization (ODS) has been considered as a further new technology for deep desulfurization of light oil [3]. This desulfurization process includes two stages: (i), oxidation in a first step; and (ii), liquid extraction at the end [4]. It is evident that the greatest advantages of the ODS process are low reaction temperature and pressure, and the expensive hydrogen gas is not used in the process. Most of the studies have been concentrated on heterogeneous molybdenum and tungsten supported on alumina Recently, Wan Abu Bakar et al. [5], reported that $\mathrm{MoO}_{3} / \mathrm{Al}_{2} \mathrm{O}_{3}$ was an active catalyst for the oxidation of dibenzothiophenic compounds. Therefore, it is interesting to explore the behavior of polymolybdate based catalyst doped with alkaline earth metal as dopant in the ODS reaction of commercial diesel in this paper.

\section{Materials}

\section{Materials and Methods}

All solvents and reactants were purchased and used without further purification. Phosphomolybdic acid hydrate (Across Organic), magnesium nitrate hexahydrate (Sigma-Aldrich), barium nitrate (Sigma-Aldrich), calcium nitrate tetrahydrate (Sigma-Aldrich) and strontium nitrate (Sigma-Aldrich), $\lambda-\mathrm{Al}_{2} \mathrm{O}_{3}$ beads 3-5 mm diameter (SigmaAldrich), tert-butyl hydroperoxide $70 \mathrm{wt} \%$ in water (Acros Organic), dimethylformamide (MERCK) were used in this research. The fuel tested was a commercial diesel fuel from Petronas, Malaysia with $440 \mathrm{ppmw}$ of sulfur content.

\section{Preparation and characterization of catalysts}

Calcium, barium, and strontium-doped $\mathrm{MoO}_{3}-\mathrm{PO}_{4} / \mathrm{Al}_{2} \mathrm{O}_{3}$ were prepared at ratio 15:85 by dissolving phosphomolybdic acid either with barium nitrate or calcium nitrate tetrahydrate or strontium nitrate in the sufficient volume of water and the solution were used for impregnation of $\mathrm{Al}_{2} \mathrm{O}_{3}$ (surface area: $292 \mathrm{~m}^{2} / \mathrm{g}$ ) at room temperature. The wet sample was dried overnight at room temperature before it was calcined at various temperatures for $5 \mathrm{~h}$ in air. XRD analysis was conducted by using Siemens D5000 crystalloflex X-Ray diffractometer equipped with $40 \mathrm{kV}$ and $40 \mathrm{~mA} \mathrm{Cu}$ target $(\lambda \mathrm{CuK \alpha})=1.54 \mathrm{~A})$ radiation. Using a step scan of $0.050^{\circ}$ and a step time of a second per step, data were collected over the range of $2 \theta$ from $20^{\circ}$ to $80^{\circ}$. FESEM-EDX analysis was accomplished by using Philips XL 40 microscope with energy of $15.9 \mathrm{kV}$ coupled with EDX analyzer and bombarded using electron gun with tungsten filament under $25 \mathrm{kV}$ resolutions to get the required magnification image.

\section{Catalytic oxidative desulfurization}

All oxidative desulfurization (ODS) reactions were conducted in a $100 \mathrm{~mL}$ round-bottom flask, equipped with a magnetic stirrer and fitted with condenser. In a typical run, the oil bath was first heated and stabilized at a constant temperature $\left(45^{\circ} \mathrm{C}\right)$. Then, $10 \mathrm{ml}$ of commercial diesel $(440 \mathrm{ppmw})$ was added to the flask, followed by the addition of sulfur/TBHP in the ratio of 3 and $0.12 \mathrm{~g}$ catalyst. The mixture was refluxed for 30 minutes under vigorous stirring at atmospheric pressure. The oxidized diesel was extracted with DMF at ratio diesel/solvent $=1.0$. The extraction process was conducted by vigorous stirring for 30 minutes followed by phase separation between diesel 
and solvent. The treated diesel was analyzed by gas-chromatography (Agilent 6890N GC) equipped with FPD detector.

\section{Results and Discussion \\ Catalytic Evaluation: Effect of alkaline earth metal dopants}

Malka and Tatibouet [6] reported that $\mathrm{Ca}$ was a promoter of $\mathrm{MoO}_{3}-\mathrm{PO}_{4} / \mathrm{Al}_{2} \mathrm{O}_{3}$ catalyst in the oxidation of methanol. In the present study, several alkaline earth metals were used to modify $\mathrm{MoO}_{3}-\mathrm{PO}_{4} / \mathrm{Al}_{2} \mathrm{O}_{3}$ catalysts. Figure 1 shows that the activity of catalysts for oxidation of commercial diesel with TBHP decreased in the order: $\mathrm{Ca} / \mathrm{MoO}_{3}$ $\mathrm{PO}_{4} / \mathrm{Al}_{2} \mathrm{O}_{3}>\mathrm{Sr} / \mathrm{MoO}_{3}-\mathrm{PO}_{4} / \mathrm{Al}_{2} \mathrm{O}_{3}>\mathrm{Ba} / \mathrm{MoO}_{3}-\mathrm{PO}_{4} / \mathrm{Ba} / \mathrm{Al}_{2} \mathrm{O}_{3}$. As reported by Chang et al. [7], molybdenum oxide was a typical example of poorly dispersed catalyst, because molybdenum oxide, such as $\mathrm{MoO}_{3}$, and alumina are considered to have an acidic character, thus weak interaction between molybdenum oxide and alumina is expected. Since alkaline earth metals possess strong basic characters, therefore it is possible to improve the dispersion of $\mathrm{MoO}_{3}$ on the alumina by the introduction of alkaline earth metals.

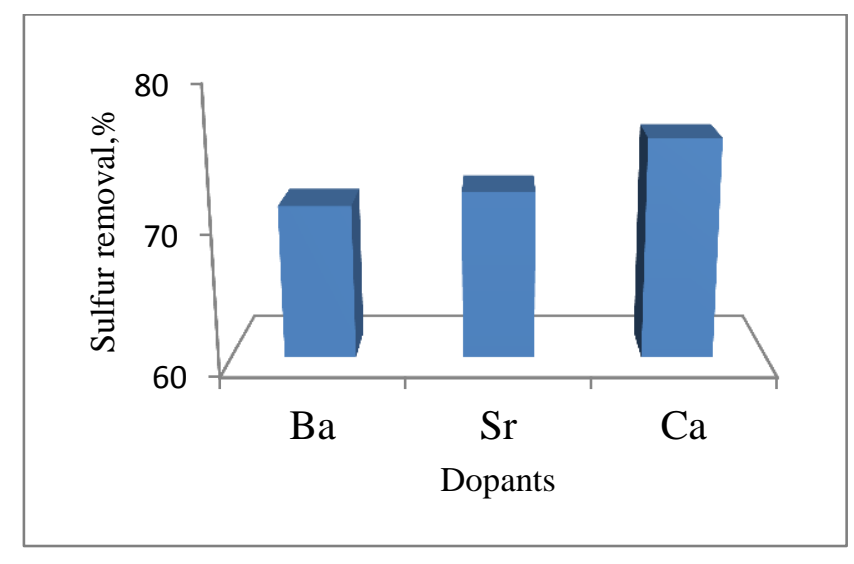

Figure 1. Effect of alkaline earth metal dopants on $\mathrm{MoO}_{3}-\mathrm{PO}_{4} / \mathrm{Al}_{2} \mathrm{O}_{3}$ catalyst calcined at $500{ }^{\circ} \mathrm{C}$ for $5 \mathrm{~h}$ in the ODS reaction of commercial diesel

\section{Effect of calcination temperature}

Figure 2 shows the effect of calcination temperatures on $\mathrm{Ca} / \mathrm{MoO}_{3}-\mathrm{PO}_{4} / \mathrm{Al}_{2} \mathrm{O}_{3}$ catalyst, calcined at 400,500 and 600 ${ }^{\circ} \mathrm{C}$. The catalytic activity increase as the calcinations temperature was increased but further increase to $600{ }^{\circ} \mathrm{C}$ would cause the decreasing of catalytic activity. This is because, the calcination temperature of $600{ }^{\circ} \mathrm{C}$ could cause agglomeration of the catalyst particles thus decreasing the surface area consequently produces less active catalyst [8]. The optimum calcinations temperature obtained was $500{ }^{\circ} \mathrm{C}$.

\section{Effect of Ca loading}

The effect of $\mathrm{Ca}$ loading was carried out in order to investigate the optimum loading towards the performance of sulfur removal as shown in Figure 3. It clearly showed that an appropriate amount of $\mathrm{Ca}$ would increase the catalytic activity of the catalyst. The optimum calcium loading was $15 \%$. The excessive addition of Ca into the catalyst decreases the sulfur removal. It was due to the excess amount of $\mathrm{Ca}$ on the catalyst surface will cause the agglomeration to occur that reduced amount of active size. 
Wan Nazwanie et al: OXIDATION OF COMMERCIAL PETRONAS DIESEL WITH TERT-BUTYL

HYDROPEROXIDE OVER POLYMOLYBDATE ALUMINA SUPPORTED CATALYST

MODIFIED WITH ALKALINE EARTH METALS

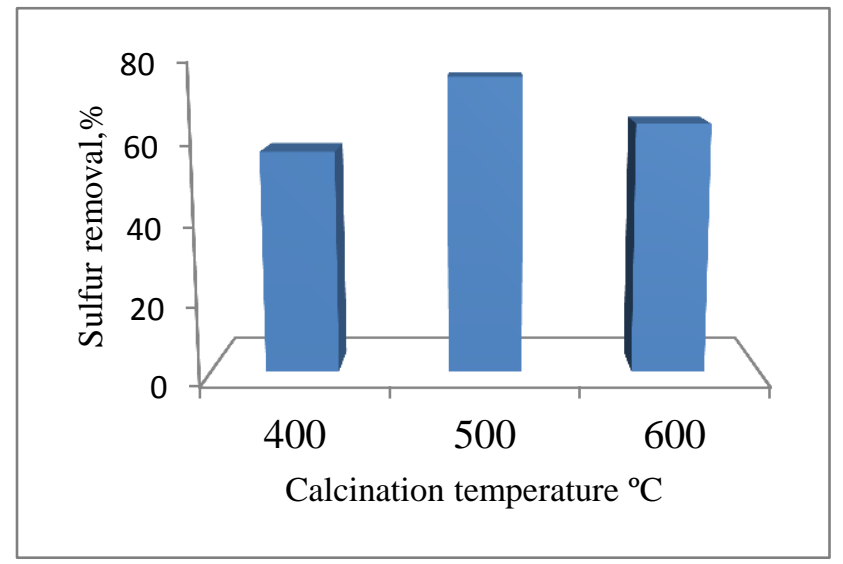

Figure 2. Effect of calcination temperature on $\mathrm{Ca} / \mathrm{MoO}_{3}-\mathrm{PO}_{4} / \mathrm{Al}_{2} \mathrm{O}_{3}$ catalyst in the ODS reaction of commercial diesel

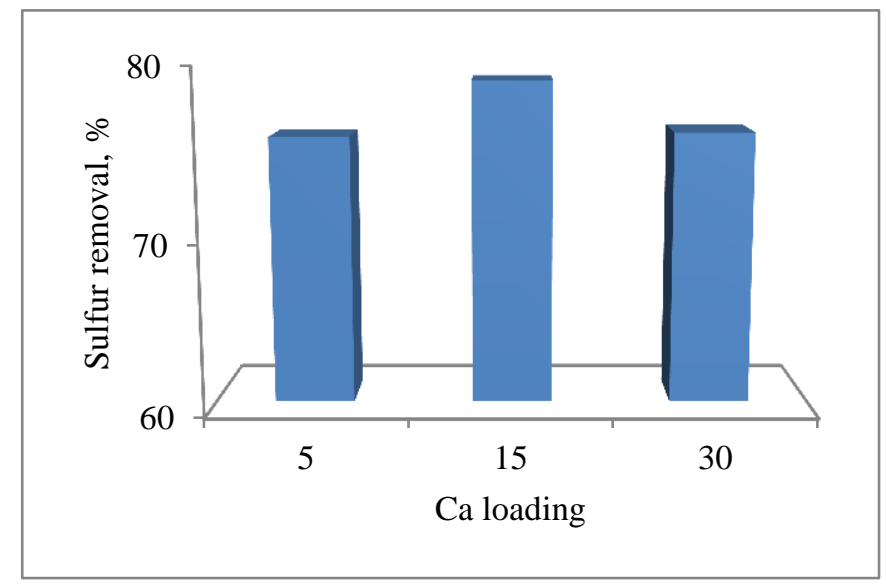

Figure 3. Effect of Ca loading on $\mathrm{Ca} / \mathrm{MoO}_{3}-\mathrm{PO}_{4} / \mathrm{Al}_{2} \mathrm{O}_{3}$ catalyst calcined at $500{ }^{\circ} \mathrm{C}$ for $5 \mathrm{~h}$ in the ODS reaction of commercial diesel

\section{Characterization of Catalyst}

Table 1 shows the textural properties of the bimetallic oxide catalysts, obtained by EDX analysis. EDX confirmed the presence of $\mathrm{Mo}, \mathrm{P}$, and $\mathrm{Ca}$ in the catalyst. It can be seen that by increasing the calcination temperatures from 400 to $600{ }^{\circ} \mathrm{C}$, the composition of Ca element was getting lower. It was probably due to the agglomeration of Mo which will hinder the $\mathrm{Ca}$ species, hence decrease the composition of this element and also diminished the catalytic activity. As shown in Figure 4, increase the calcination temperature from 400 to $600{ }^{\circ} \mathrm{C}$ leads to the formation of aggregates and agglomerates with undefined shapes and mixture of larger and smaller particles size. 
Table 1. Elemental analysis of the monometallic and bimetallic oxide catalysts

\begin{tabular}{lcccc}
\hline Catalysts & $\begin{array}{c}\text { Calcination T } \\
\left({ }^{\circ} \mathbf{C}\right)\end{array}$ & $\begin{array}{c}\text { Loading Mo } \\
(\text { wt. \%) }\end{array}$ & $\begin{array}{c}\text { Loading P } \\
(\text { wt.\%) }\end{array}$ & $\begin{array}{c}\text { Loading Ca } \\
(\text { wt.\%) }\end{array}$ \\
\hline $\mathrm{MoO}_{3}-\mathrm{PO}_{4} / \mathrm{Al}_{2} \mathrm{O}_{3}$ & 500 & 15 & 0.63 & - \\
$\mathrm{Ca} / \mathrm{MoO}_{3}-\mathrm{PO}_{4} / \mathrm{Al}_{2} \mathrm{O}_{3}$ & 400 & 16.30 & 2.16 & 0.5 \\
$\mathrm{Ca} / \mathrm{MoO}_{3}-\mathrm{PO}_{4} / \mathrm{Al}_{2} \mathrm{O}_{3}$ & 500 & 15 & 3.10 & 0.33 \\
$\mathrm{Ca} / \mathrm{MoO}_{3}-\mathrm{PO}_{4} / \mathrm{Al}_{2} \mathrm{O}_{3}$ & 600 & 16 & 3.3 & 0.14 \\
\hline
\end{tabular}
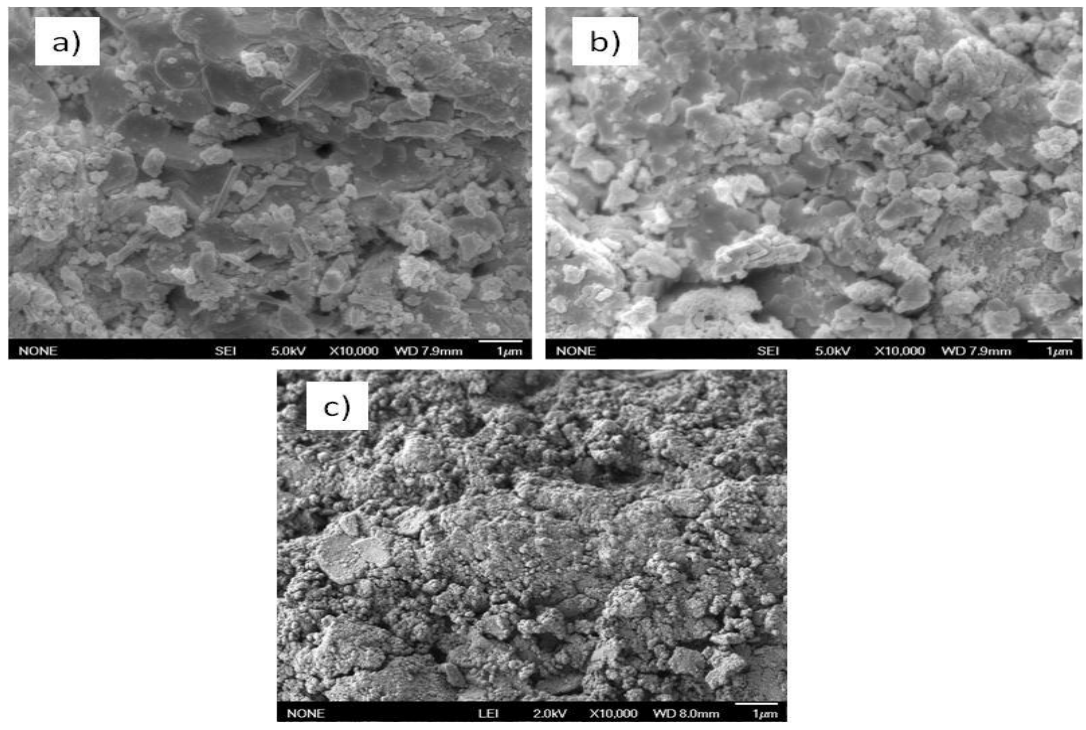

Figure 4. FESEM micrographs of $\mathrm{Ca} / \mathrm{MoO}_{3}-\mathrm{PO}_{4}(15: 85) / \mathrm{Al}_{2} \mathrm{O}_{3}$ calcined at a) $\left.400^{\circ} \mathrm{C} \mathrm{b}\right) 500^{\circ} \mathrm{C}$ c) $600^{\circ} \mathrm{C}$. Magnification $10 \mathrm{k}$, scale bar $1 \mu \mathrm{m}$

The XRD diffraction patterns of the $\mathrm{Ca} / \mathrm{MoO}_{3}-\mathrm{PO}_{4} / \mathrm{Al}_{2} \mathrm{O}_{3}$ catalysts (Figure 5) indicate that the catalyst calcined at $500{ }^{\circ} \mathrm{C}$ and $700{ }^{\circ} \mathrm{C}$ possess amorphous structure which made the molybdenum phase undetectable suggesting the presence of high dispersion monolayer of Mo on the catalyst. This phenomenon could be the reason of higher catalytic activity of $\mathrm{Ca} / \mathrm{MoO}_{3}-\mathrm{PO}_{4} / \mathrm{Al}_{2} \mathrm{O}_{3}(15: 85)$ catalyst calcined at $500{ }^{\circ} \mathrm{C}$. The oxide peak does not appear in the diffractogram probably due to the small particle size of $\mathrm{Ca}(<4 \mathrm{~nm})$ which is beyond XRD detection limit and low Ca loading in the catalyst as shown in EDX data.

Increasing the calcination temperature at $900{ }^{\circ} \mathrm{C}$ led to the formation of crystalline $\mathrm{Mo}_{9} \mathrm{O}_{26}$ with new peaks obtained at $2 \theta$ value $=21.760^{\circ}\left(\mathrm{I}_{100}\right)$ and $25.85^{\circ}\left(\mathrm{I}_{60}\right)$ which attributed to base centered monoclinic phase. As shown in the diffractogram at $900{ }^{\circ} \mathrm{C}$, the phase was dominated by alumina support which assigned as $\mathrm{Al}_{2} \mathrm{O}_{3}$ rhombohedral occurred at $2 \theta=35.10^{\circ}\left(\mathrm{I}_{100}\right), 43.32^{\circ}\left(\mathrm{I}_{94}\right), 57.41^{\circ}\left(\mathrm{I}_{79}\right), 25.85^{\circ}\left(\mathrm{I}_{74}\right)$. It was claimed by Jones et al. [9] that catalysts calcined at temperatures above $500{ }^{\circ} \mathrm{C}$ showed high crystallinity. It was observed that the higher crystallinity and crystallize size of sample was observed at $900{ }^{\circ} \mathrm{C}$ than those treated at $500{ }^{\circ} \mathrm{C}$ and $700{ }^{\circ} \mathrm{C}$ suggesting that sample prepared at high temperature aggregate and agglomerate to form larger particle size with high crystallinity and also showed clear pattern of metal oxide. This results was agreement with our catalytic activity where the increased of calcinations temperature diminished the catalytic activity. 


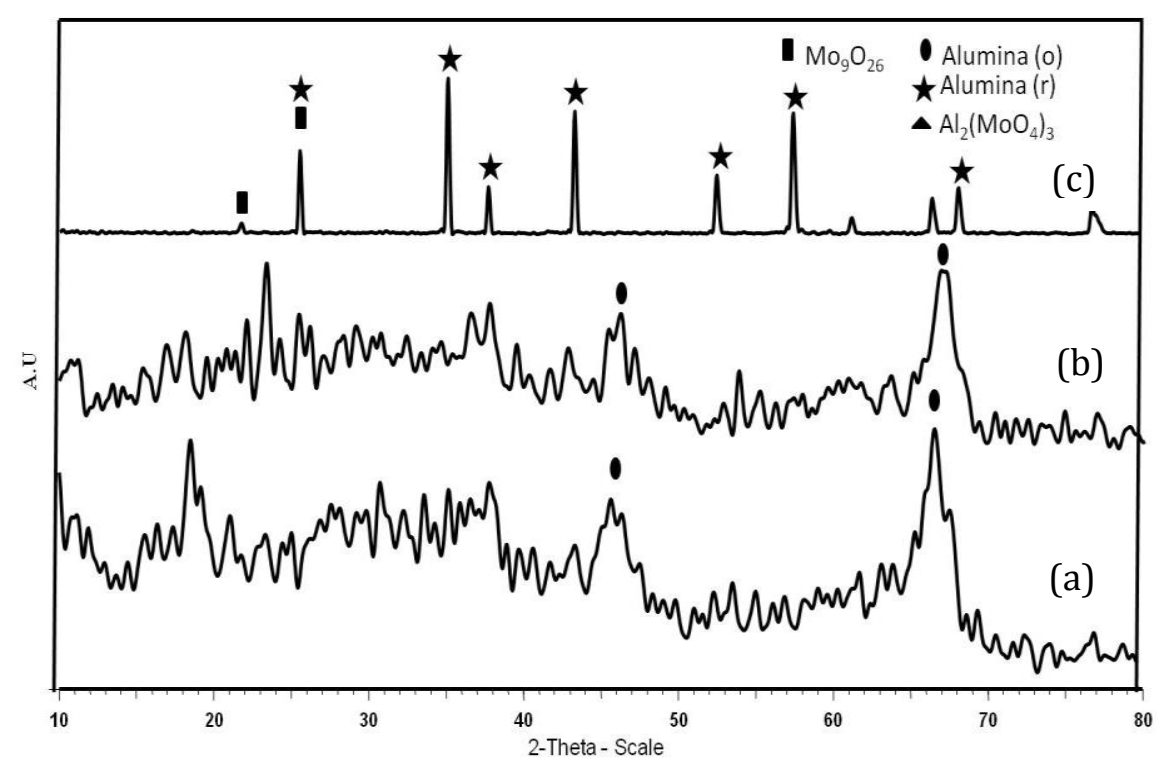

Figure 5. XRD diffractogram patterns of $\mathrm{Ca} / \mathrm{MoO}_{3}-\mathrm{PO}_{4} / \mathrm{Al}_{2} \mathrm{O}_{3}$ calcined at (a) $500^{\circ} \mathrm{C}$, (b) $700^{\circ} \mathrm{C}$ and (c) $900^{\circ} \mathrm{C}$.

\section{Mechanistic Study}

The proposed peroxidic oxidation mechanism of DBT on $\mathrm{Ca} / \mathrm{MoO}_{3}-\mathrm{PO}_{4} / \mathrm{Al}_{2} \mathrm{O}_{3}$ catalyst with TBHP is shown in Figure 6. The reaction pathway proceeded initially through the nucleophilic attack of TBHP on $\mathrm{Ca} / \mathrm{MoO}_{3}-\mathrm{PO}_{4} / \mathrm{Al}_{2} \mathrm{O}_{3}$ to form species (1). The oxidation process must proceed by nucleophilic attack of the sulfur in the DBT (2) on the positively charged peroxometallic complex (1) to form DBT sulfoxide (3) and regenerated polymolybdate species, respectively. Subsequently, the sulfoxide (3) undergoes further oxidation to form DBT sulfone (4) [2].

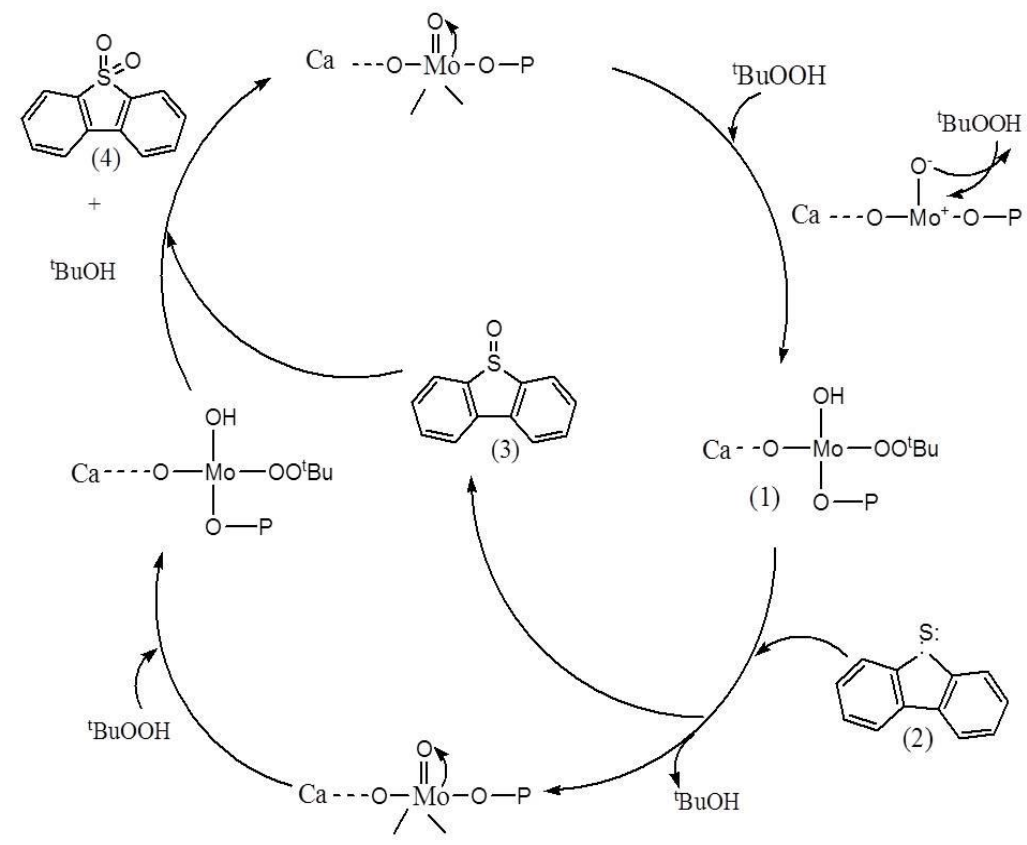

Figure 6. A proposed cyclic mechanism for the oxidation of dibenzothiophene by TBHP in the presence of $\mathrm{Ca} / \mathrm{MoO}_{3}-\mathrm{PO}_{4} / \mathrm{Al}_{2} \mathrm{O}_{3}$ catalyst 


\section{Conclusion}

Sulfur level in the Malaysia commercial diesel can be reduced from about 440 ppmw to 92 ppmw of sulfur at $45^{\circ} \mathrm{C}$ under mild condition using polymolybdate based catalyst with alkaline earth metal as dopant. Further improvement on $\mathrm{MoO}_{3}-\mathrm{PO}_{4} / \mathrm{Al}_{2} \mathrm{O}_{3}$ catalyst using different dopants indicated that oxidative desulfurization (ODS) for commercial diesel has been achieved over the $\mathrm{Ca} / \mathrm{MoO}_{3}-\mathrm{PO}_{4} / \mathrm{Al}_{2} \mathrm{O}_{3}(15: 85)$ calcined at $500{ }^{\circ} \mathrm{C}$. The catalyst had good activity in the oxidative desulfurization with TBHP in diesel fuel. These results may indicate that alumina supported polymolybdate based catalyst has the potential to be used as catalyst in Cat-ODS to meet the future regulation of sulfur in diesel fuel.

\section{Acknowledgement}

The authors thank the Department of Chemistry, Faculty of Science, Universiti Teknologi Malaysia, Johor as well as to FRGS vot 4F195 for funding the project and Ministry of Higher Education (MOHE).

\section{References}

1. Chica, A., Corma, A. and Dómine M. E. (2006). Catalytic oxidative desulfurization (ODS) of diesel fuel on a continuous fixed-bed reactor. Journal of Catalysis, 242: 299 - 308.

2. Abdullah, W. N. W., Bakar, W. A. W. A. and Ali, R. (2014). Catalytic oxidative desulfurization of diesel fuel utilizing a polymolybdate alumina supported catalyst: Characterization, catalytic activity and mechanistic study. Reaction Kinetic Mechanism and Catalyst, 114:547 - 560.

3. Lifeng, W., Baode, S., Frances, H. Y. and Ralph, T. Y. (2012). Effects of aromatics on desulfurization of liquid fuel by p-complexation and carbon adsorbents. Chemical Engineering Society, 73:208 - 217.

4. Tam, P. S., Kittrell, J. R. and Eldridge J. W. (1990). Desulfurization of fuel oil by oxidation and extraction. 1. Enhancement of extraction oil yield. Industrial \& Engineering Chemistry Research, 29(3): 321 - 324.

5. Wan Abu Bakar, W. A., Ali, R., Abdul Kadir, A. A. and Wan Mokhtar, W. A. (2012). Effect of transition metal oxides catalyst on oxidative desulfurization of model diesel. Fuel Processing Technology, 101: 78 - 84.

6. Malka, K. and Tatiboue, J. M. (1998). A two-step preparation of silica-supported calcium-molybdenum catalysts. Journal of Catalysis, 175: $204-212$.

7. Chang, J., Wang, A., Liu, J., Li, X. and Hu, Y. (2010). Oxidation of dibenzothiophene with cumene hydroperoxide on $\mathrm{MoO}_{3} / \mathrm{SiO}_{2}$ modified with alkaline earth metals. Catalysis Today, 149: 122 - 126.

8. Wan Abdullah, W. N., Wan Abu Bakar W. A., Ali R. and Embong Z. (2015). Oxidative desulfurization of commercial diesel catalyzed by tert-butyl hydroperoxide polymolybdate on alumina: Optimization of BoxBehnken design. Clean Technologies and Environment Policy, 17: 433 - 441.

9. Jones, C., Cole, K. J., Taylor, S. H., Crudace, M. J. and Hutchings, G. J. (2009). Copper manganese oxide catalysts for ambient temperature carbon monoxide oxidation: Effect of calcination on activity. Journal of Molecular Catalysis A: Chemical, 305:121 - 124. 